\title{
Sistem dan Politik Ekonomi Islam dalam Mewujudkan Kesejahteraan
}

\author{
Arim Nasim ${ }^{1 *}$ \\ ${ }^{1}$ Program Studi Ilmu Ekonomi dan Keuangan Islam, Universitas Pendidikan Indonesia, Bandung, Indonesia
}

ARTICLE INFO ABSTRACT

\section{Keywords}

Sistem Ekonomi Islam, Politik

Ekonomi Islam, Kapitalisme

\section{*Correspondence}

arim.nasim@upi.edu

\section{Article History}

Received 2 April 2018

Accepted 28 April 2018

Published on-line 10 May 2018
Makalah ini bertujuan untuk memberikan gambaran pemahaman tentang kegagalan sistem ekonomi kapitalis dalam menyejahterakan umat manusia dan memberikan gambaran bagaimana sistem ekonomi islam mampu mewujudkan kesejahteraan umat manusia. Makalah ini disusun dengan metode kualitatif dengan pendekatan Critical Theory. Berdasarkan hasil pembahasan maka dapat disimpulkan kegagalan sistem ekonomi kapitalis dalam menyejahterakan umat manusia disebabkan karena kesalahan yang mendasar dari sistem tersebut yaitu, pandangan tentang konsep kelangkaan (scarcity) barang dan jasa, pandangan tentang konsep nilai (value) suatu barang dan jasa yang dihasilkan serta pandangan tentang konsep harga dan peranannya dalam produksi, konsumsi, dan distribusi. Politik Ekonomi Islam melalui mekanisme langsung dan tidak langsung mampu memberikan jaminan kesejahteraan kepada umat manusia dan zakat maupun pajak dalam Sistem Ekonomi Islam bukan merupakan sumber utama pemasukan negara.

\section{PENDAHULUAN}

Menurut Badan Pusat Statistik (2017), angka kemiskinan masih sangat tinggi mencapai 27,77 juta jiwa. Sementara dalam skala internasional, Kegagalan dan kerusakan yang disebabkan oleh sistem ekonomi kapitalis semakin nyata dan jelas, menurut Laporan Global Hunger Index (GHI) yang dibuat oleh International Food Policy Research Institute, menyebutkan bahwa sepanjang tahun 2010 terdapat 1 miliar penduduk dunia yang mengalami kelaparan. Tingkat kelaparan di 25 negara bahkan sudah mencapai level ekstrem (extremely alarming), sementara untuk negara lainnya masuk level serius (serious alarming). Tiga faktor yang digunakan untuk mengukur GHI tersebut adalah proporsi masyarakat yang kekurangan pangan di suatu negara, jumlah anak-anak dengan berat badan di bawah standard, dan tingkat kematian anak-anak (www.ifpri.org).

Sementara ketika sistem ekonomi islam di terapkan dalam wadah Negara kesatuan khilafah Islamiyah, sistem ekonomi islam mampu memberikan jaminan kesejahteraan bagi seluruh umat manusia sebagaimana yang dikemukakan oleh Will Durant, dalam The Story of Civilization, vol. XIII, p 151, menggambarkan bagaimana sistem islam yang diterapkan oleh Khalifah mampu memberikan kesejahteraan bagi umat manusia baik muslim maupun non-muslim :

"Para Khalifah telah memberikan keamanan kepada manusia hingga batas yang luar biasa besarnya bagi kehidupan dan kerja keras mereka. Para Khalifah itu juga telah menyediakan berbagai peluang untuk siapapun yang memerlukannya dan memberikan kesejahteraan selama berabad-abad dalam wilayah yang sangat luas, dimana fenomena seperti itu belum pernah tercatat (dalam sejarah) setelah zaman mereka. Kegigihan dan kerja keras mereka menjadikan pendidikan tersebar luas, hingga berbagai ilmu, sastra, filsafat dan seni mengalami kemajuan luar biasa, yang menjadikan Asia Barat sebagai bagian dunia yang paling maju peradabannya selama lima abad".

Berdasarkan latar belakang tersebut, makalah atau paper ini disusun untuk memberikan gambaran tentang kegagalan sistem ekonomi kapitalis dalam menyejahterakan umat manusia. Selain itu, gambaran keberhasilan sistem ekonomi islam yang diterapkan oleh Negara Khilafah Islamiyah mampu mewujudkan kesejahteraan umat manusia, maka pertanyaan yang ingin di jawab serta tujuan yang ingin dicapai melalui penelitian ini adalah: Pertama, apakah yang menyebabkan kegagalan sistem ekonomi kapitalis dalam menyejahterakan manusia? Jawaban atas pertanyaan ini akan memberikan gambaran pemahaman tentang kegagalan sistem ekonomi kapitalis dalam menyejahterakan rakyat. Kedua, Bagaimana mekanisme politik ekonomi islam dalam mewujudkan jaminan kesejahteraan umat manusia? Jawaban atas pertanyaan ini akan memberikan gambaran tentang mekanisme sistem ekonomi islam yang diterapkan oleh negara dapat memberikan jaminan kesejahteraan kepada seluruh umat manusia khususnya mereka yang menjadi warga Negara islam. Ketiga, Bagaimana mekanisme pembiayaan Negara untuk 
mewujudkan kesejahteraan tersebut? Jawaban atas pertanyaan ini akan memberikan gambaran sistem ekonomi islam di bidang APBN dan Kebijakan fiscal.

\section{METODE PENELITIAN/KAJIAN}

Makalah atau penelitian ini menggunakan metode kualitatif. Menurut Anis (2011), Penelitian kualitatif adalah penelitian yang dilakukan dalam setting tertentu yang ada dalam kehidupan ril (alamiah) dengan maksud menginvestigasi dan memahami fenomena: apa yang terjadi, mengapa terjadi dan bagaimana terjadinya?. Jadi riset kualitatif adalah berbasis pada konsep "going exploring" yang melibatkan in-depth and case-oriented study atas sejumlah kasus atau kasus tunggal. Tujuan utama penelitian kualitatif adalah membuat fakta mudah dipahami (understandable) dan kalau memungkinkan (sesuai modelnya) dapat menghasilkan hipotesis baru atau minimal asumsi baru.

Pendekatan penelitian yang digunakan adalah Critical Theory menurut Neumann dalam Turiman (2011), pendekatan critical lebih bertujuan untuk memperjuangkan ide peneliti agar membawa perubahan substansial pada masyarakat. Penelitian bukan lagi menghasilkan karya tulis ilmiah yang netral/tidak memihak dan bersifat apolitis, namun lebih bersifat alat untuk mengubah institusi sosial, cara berpikir, dan perilaku masyarakat ke arah yang diyakini lebih baik. Karena itu, dalam pendekatan ini pemahaman yang mendalam tentang suatu fenomena berdasarkan fakta lapangan perlu dilengkapi dengan analisis dan pendapat yang berdasarkan keadaan pribadi peneliti, asalkan didukung argumentasi yang memadai.

\section{TINJAUAN TEORI : KONSEP WALFARE STATE}

\subsection{Konsep Walfare State dalam Sistem Kapitalis}

Konsep Negara kesejahteraan dalam sistem kapitalis sebenarnya muncul pertama kali di Eropa. Hal itu terjadi ketika memasuki abad 19, sistem kapitalis hampir roboh baik karena kerusakan yang ditimbulkannya maupun munculnya ideologi sosialisme marxisme. Oleh karena itu, beberapa pemikir kapitalis memunculkan ide sosialisme Negara untuk mengalihkan perhatian publik terhadap ide sosialisme marxisme, tapi ide tersebut belum berhasil malah justru sistem kapitalis semakin tampak kebangkrutannya maka muncullah ide tambahan yaitu keadilan sosial yaitu Negara menjalankan beberapa pelayanan sosial dalam sistem kapitalisme. Dengan dua ide ini yaitu sosialisme Negara dan keadilan sosial maka sistem kapitalisme bisa bertahan di Eropa sampai saat ini. Karena itu, menurut Husodo dalam Edi (2007), Konsep Negara Kesejahteraan ini dipandang sebagai bentuk keterlibatan negara dalam memajukan kesejahteraan rakyat setelah menyuatnya bukti-bukti empirik mengenai kegagalan pasar (market failure) pada masyarakat kapitalis dan kegagalan negara (state failure) pada masyarakat sosialis.

\subsection{Konsep Kesejahteraan dalam Sistem Islam}

Islam mendefinisikan kesejahteraan sebagai kondisi saat seseorang dapat mewujudkan semua tujuan (maqashid) syariah, yakni: (1) terlindungi kesucian agamanya; (2) terlindungi keselamatan dirinya; (3) terlindungi akalnya; (4) terlindungi kehormatannya; (5) terlindungi hak miliknya/hak ekonominya (Hizbut Tahrir Indonesia ,2011) . Oleh karena itu, dalam pandangan Islam, bukan hanya merupakan hasil dari kebijakan ekonomi yang lahir dari sistem ekonomi tapi berhubungan dengan kebijakan-kebijakan yang lainnya yang lahir dari sistem yang lainnya seperti sistem hukum, sistem politik, sistem budaya dan sistem pergaulan sosial. Dalam konteks kesejahteraan ekonomi, Kesejahteran yang dijamin dalam islam merupakan implementasi dari Poltik Ekonomi Islam. Politik Ekonomi Islam seperti yang dijelaskan oleh Abdurahman al-Maliki (2001) dalam bukunya, As-Siyâsah al-Iqtishâdiyah al-Mutslâ (Politik Ekonomi Ideal) adalah jaminan pemenuhan atas pemuasan semua kebutuhan primer (sandang, pangan, dan papan) setiap orang serta pemenuhan kebutuhan sekunder dan tersiernya sesuai dengan kadar kemampuannya sebagai individu yang hidup dalam masyarakat tertentu yang memiliki gaya hidup yang khas.

\section{PEMBAHASAN}

\subsection{Kegagalan Sistem Ekonomi Kapitalis dalam Mensejahterakan Umat Manusia}

Kegagalan kapitalisme dalam menciptakan kesejahteraan masyarakat dan memberikan kesalahan bukan hanya terkait dengan problematik praktikalnya, tapi diyakini berangkat dari kesalahan yang bersifat sangat fundamental, yakni kapitalisme sejak awal mulai dari asas, pandangan tentang problematika ekonomi dan sejumlah gagasan-gagasan derivasinya memang telah keliru. Kapitalisme sebagai sebuah ideologi sekuler telah menghilangkan peran agama dalam pengaturan ekonomi, dari sinilah kemudian muncul paradigma yang salah yang membangun sistem ekonomi kapitalis. Menurut Anabhani (1996), ada 3 hal kesalahan mendasar dari sistem ekonomi kapitalis yang dirancang oleh Adam Smith sebagai peletak dasar sistem ekonomi kapitalis, yaitu: Pertama, pandangan tentang konsep kelangkaan (scarcity) barang dan jasa. Kedua, pandangan tentang konsep nilai (value) suatu barang dan jasa yang dihasilkan. Ketiga, pandangan tentang konsep harga dan peranannya dalam produksi, konsumsi, dan distribusi.

Konsep kelangkaan barang dan jasa dalam sistem ekonomi kapitalis muncul karena tidak membedakan antara pengertian kebutuhan (need) dengan keinginan (want). Keinginan (want) manusia memang tidak terbatas dan cenderung untuk terus bertambah dari waktu ke waktu. Sementara kebutuhan manusia tidaklah demikian. Kebutuhan pokok manusia berupa pangan, sandang dan papan dalam kenyataannya adalah terbatas.

Kebutuhan manusia menurut pandangan sistem ekonomi kapitalis adalah sesuatu yang diinginkan manusia tanpa memandang apakah itu bermanfaat atau membahayakan manusia, apakah dapat menyejahterakan manusia atau tidak? Padahal menentukan suatu kebutuhan berdasarkan keinginan manusia semata sangatlah berbahaya. Ini terlihat dari bagaimana masyarakat di negaranegara penganut paham kapitalisme harus menerima kenyataan bahwa sebagian dari mereka membutuhkan narkotika, heroin, judi, pornoaksi dan pornografi serta pelacuran meskipun itu semua sesungguhnya sangat berbahaya.

Kekeliruan lainnya adalah anggapan bahwa kebutuhan manusia terbatas pada yang bersifat materi saja, padahal manusia juga mempunyai kebutuhan lain seperti kebutuhan ruhiyah (beragama), kebutuhan moral, kebutuhan akan kasih sayang sesama manusia, kebutuhan untuk berketurunan, dan lain-lain. Akibatnya mereka tidak pernah memperhatikan masalah-masalah 
ketinggian moral, spiritualitas, nilai-nilai ketakwaan dan semangat pencarian keridaan Allah, yang semestinya harus dijadikan landasan dalam membangun peradaban.

Berpangkal dari pandangan bahwa problematika ekonomi adalah kelangkaan, maka kapitalisme memproduksi kekayaan dengan porsi yang jauh lebih besar daripada distribusi untuk memenuhi kebutuhan masyarakat. Atas dasar inilah, maka sistem ekonomi kapitalis hanya mengarah kepada satu tujuan, yaitu meningkatkan kekayaan negara secara total, semboyan kapitalisme yang berupa "berproduksi untuk dapat berproduksi lebih besar" menyebabkan keserakahan dan kehidupan yang materialistik. Melimpahnya produksi tidak lagi menjadi alat untuk mencapai tujuan yang lebih luhur, karena ia telah menjadi tujuan itu sendiri. Akibat mementingkan produksi atas segala-galanya itu, kapitalisme pada umumnya merusak ekologi yang seharusnya dilestarikan. Polusi udara, sungai dan lautan, sesungguhnya berasal dari semangat kapitalisme yang bernafsu menjalankan produksi tanpa batas.

Sementara mengenai nilai barang dan jasa, kapitalisme menyatakan bahwa nilai suatu barang dan jasa sangatlah subyektif sehingga sistem ekonomi kapitalis menganggap nilai barang dan jasa sebagai sesuatu yang bersifat nisbi (relatif), bukan hakiki. Menurut mereka penilaian terhadap nilai suatu barang dan jasa sangat ditentukan oleh pandangan setiap orang terhadap tingkat kepuasan terakhir yang dapat dia rasakan ketika dia mengkonsumsi barang dan jasa tersebut.

Dalam bidang produksi, konsumsi dan distribusi sistem ekonomi kapitalis menyatakan bahwa mekanisme harga merupakan metode yang tepat untuk mendistribusikan barang dan jasa kepada anggota masyarakat, akibatnya kebebasan kepemilikan dan kebebasan bekerja menjadi landasan bagi anggota masyarakat tanpa peduli yang lain. Maka hal yang wajar jika di negara-negara Barat yang kaya sekalipun masih banyak dijumpai orang-orang miskin dengan perkampungan kumuhnya, pengemis dan gelandangan yang selalu terlihat di sudut-suduk kota.

Kebijakan pembangunan ekonomi Indonesia, sejak Jaman Orde Baru sampai saat ini walaupun mengklaim melaksanakan sistem ekonomi pancasila atau demokrasi ekonomi, tapi kenyataannya sistem ekonomi yang diterapkan adalah sistem ekonomi kapitalis atau sistem ekonomi liberal. Penerapan sistem ekonomi Indonesia semakin kapitalis sejak Indonesia menjalankan konsensus Washington untuk mengatasi krisis ekonomi tahun 1998. Konsensus Washington sebagai dasar kebijakan ekonomi dengan kebijakan utamanya : (1) pelaksanan kebijakan anggaran ketat, termasuk penghapusan subsidi negara dalam berbagai bentuknya, (2) pelaksanaan liberalisasi sektor keuangan, (3) pelaksanaan liberalisasi sektor perdagangan, dan (4) pelaksanaan privatisasi BUMN.

Akibat dari liberalisasi dan pelaksanaan konsesus washington, maka Sumber daya alam yang harus dikuasai oleh negara, justru dikuasai dan di monopoli pihak swasta baik lokal maupun asing. Sebagai contoh Tabel 1 di bawah ini :

Tabel 1. Pengelolaan sumber daya alam di Indonesia

\begin{tabular}{lccc}
\hline Komoditas & Swasta & $\begin{array}{c}\text { Produksi } \\
\text { BUMN }\end{array}$ & Total \\
\hline Gas Bumi (Juta MSCFD) & 6.5 & 1.2 & 7.7 \\
Minyak Mentah (ribu barel & 663.1 & 171.9 & 835 \\
per hari) & & & \\
Batubara (juta ton) & 466.3 & 14.6 & 480.9 \\
Emas (ton) & 69.3 & 2.9 & 72.2 \\
Nikel (juta ton) & 36.2 & 9.4 & 45.7 \\
\hline
\end{tabular}

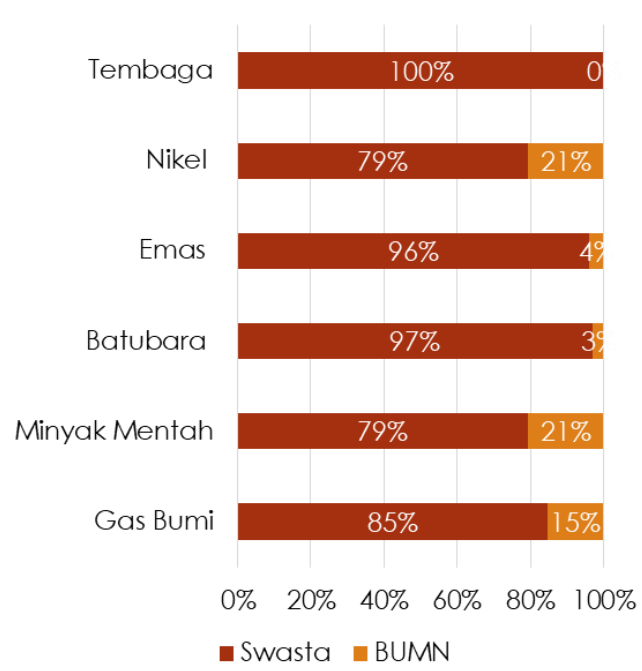

Gambar 1. Persentase pengelolaan sumber daya alam di Indonesia Sumber : Kementerian ESDM, laporan korporasi tahun 2012

Pada tahun 2015 bank dunia merilis data yang menunjukan bahwa pertumbuhan ketimpangan ekonomi Indonesia tertinggi di Asia Timur. Bahkan dalam distribusi aset lebih memprihatinkan, yaitu rasio gini penguasaan lahan mencapai angka $0,72 \%$ ini berati rasio gini lebih tinggi dari pada pendapatan. Badan Pertanahan Nasional mencatat $56 \%$ aset berupa tanah, properti dan perkebunan di Indonesia hanya dikuasai oleh sekitar $0,2 \%$ penduduk Indonesia.

Konsensus Washington dan liberalisasi SDA semakin massif di masa Jokowi. Janji Jokowi membeli kembali Indosat dan Aneka Tambang yang dijual Megawati hanya retorika belaka, yang terjadi justru malah merencanakan menjual lagi 4 BUMN yakni: PT Jasa Marga, PT Waskita Karya, PT Adhi Karya dan PT Aneka Tambang walaupun dengan bahasa sekuritisasi asset. Bahkan 
JKPIs, Vol. 1 No. 1, 2018 | 11

sebelumnya Pemerintahan Jokowi telah mengeluarkan paket ekonomi yang ke -10 yaitu membuka $100 \%$ investasi asing bagi 35 bidang usaha yang selama ini masuk dalam kategori Daftar Negatif Investasi (DNI) atau tertutup untuk investasi asing. Usaha yang dibuka itu mencakup 35 bidang, antara lain jasa penunjang kesehatan, farmasi, pariwisata dan industri film, dan pengusahaan jalan tol. Pemerintah melalui Kementerian Perhubungan juga akan menyerahkan pengelolaan 30 pelabuhan dan bandara kepada pihak swasta dan Badan Usaha Milik Negara (BUMN). Bahkan pemerintah tidak berdaya ketika Free Port memaksa perpanjangan kontrak sampai tahun 2041 dan menolak divestasi saham sebesar $51 \%$, ironisnya PT free port malah mendapat keringanan Pajak menjadi $25 \%$ dari yang seharusnya $35 \%$.

Karena sumber daya alam diserahkan ke swasta, maka untuk membiayai Negara pemerintah mengandalkan pajak dan penambahan utang. Akhir tahun ini untuk bertambah lagi, Menteri Koordinator Bidang Perekonomian, Darmin Nasution mengakui, pemerintah Jokowi-JK berencana menambah porsi penerbitan Surat Berharga Negara (SBN) yang akan dimasukkan dalam Rancangan Anggaran Pendapatan dan Belanja Negara Perubahan (R-APBNP) 2017. Nilai surat hutang tersebut mencapai Rp 467,3 triliun atau naik Rp 67,3 triliun dibandingkan target yang ditetapkan pemerintah dalam APBN 2017 sebesar Rp 400 triliun.

Untuk meningkatkan penerimaan pajak, pemerintah mengeluarkan kebijakan tax amnesty. kebijakan ini justru semakin dzalim terhadap rakyat kecil karena orang-orang kaya yang mengemplang pajak dan menghindari pajak, seharusnya mereka membayar antara 5 persen sampai $30 \%$ tapi dengan Tax Amnesty mereka sangat diringankan cukup membayar antara 2 - $3 \%$ saja dan itu pun akan dengan cepat mereka dapatkan kembali dengan bunga deposito yang mereka hasilkan antara 7 -9\%. Kondisi ini akan semakin memperkaya para kapitalis dan memperlebar kesenjangan ekonomi karena rakyat kecil yang patuh bayar pajak terus dipaksa dan diancam harus bayar pajak 5 - 30 persen. Penderitaan rakyat dan kehancuran ekonomi semakin cepat dengan kebijakan pencabutan subsidi di berbagai sektor.

\subsection{Sistem dan politik Ekonomi Islam dalam mewujudkan kesejahteraan Rakyat.}

Salah satu cabang syariat terpenting yang saat ini banyak dilupakan adalah syariat ekonomi, terutama terkait dengan ekonomi makro. Syariat islam memandang perkara ekonomi menjadi 2 bagian, yaitu ilmu ekonomi yang berhubungan dengan soal bagaimana suatu barang atau jasa diproduksi, misalnya teknik industri, manajemen atau pengembangan sumber daya baru, islam tidak mengatur secara khusus tentang ilmu ekonomi. Sistem ekonomi yang berhubungan dengan pengurusan soal pemuasan kebutuhan dasar tiap individu di dalam masyarakat serta upaya mewujudkan kemakmurannya , dan ini adalah subyek dari sistem ekonomi Islam dan mewajibkan bagi setiap muslim termasuk negara untuk terikat dengannya, sistem ekonomi islam menurut Anabhani (1996) meliputi : Pertama, konsep kepemilikan; kedua: penggunaan hak milik; dan ketiga: distribusi kekayaan di antara individu.

Tentang hal kepemilikan, Islam mengatur sedemikian rupa, sehingga memungkinkan individu untuk memuaskan kebutuhannya seraya tetap menjaga hak-hak masyarakat. Untuk itulah islam membagi kepemilikan menjadi 3, yaitu : milik pribadi , milik umum atau milik negara.

Penggunaan hak milik adalah salah satu kunci dalam sistem ekonomi. Islam mendorong warga dari khilafah, baik lelaki maupun wanita, baik Muslim maupun kafir dzimmi untuk menggunakan hak milik dan mengejar keuntungan dalam jalan yang bebas hambatan dan memuaskan kebutuhan mereka tanpa harus mengakibatkan eksploitasi ataupun korupsi yang ditimbulkan dari aktifitas mereka. Islam juga mendorong pemberian shadaqah, hibah, pinjaman tanpa riba (qardhul hasan) dan sejenisnya. Pada saat yang sama islam melarang penumpukan kekayaan, pemborosan atau pembelanjaan untuk mengejar hal-hal yang haram.

Kepemilikan umum mencakup sumber alam-seperti minyak bumi, tambang emas, perak, tembaga, dan lain-lain; benda-benda yang pembentukannya tidak mungkin dimiliki individu-seperti masjid, jalan raya; juga benda-benda vital yang dibutuhkan dan dicari-cari oleh manusia dan memiliki jumlah kandungan (deposit) yang amat besar, misalnya sumber mata air. Pengelolaannya dilakukan oleh negara sebagai wakil umat dan digunakan untuk kemakmuran rakyat dan diusahakan semaksimal mungkin dalam pengelolaannya tidak menimbulkan kerusakan baik lingkungan, ekosistem maupun sosial.

Distribusi kekayaan dan kemakmuran di dalam masyarakat adalah suatu faktor kritis dalam menentukan kecukupan sumber daya bagi masyarakat untuk memenuhi kebutuhan mereka. Oleh karena itulah Islam menjadikan distribusi sebagai problematika utama ekonomi , maka Bagi mereka yang tidak mampu memenuhi kebutuhannya, negara (khilafah) mengurusinya dengan kekayaan yang terkumpulkan dari harta milik umum, harta milik negara dan zakat yang dibayarkan oleh rakyat.

Berdasarkan paradigm tersebut, maka Islam telah menetapkan politik ekonomi dan mekanisme ekonomi untuk menjamin kesejahteraan umat manusia.

\subsubsection{Politik Ekonomi Islam}

Politik Ekonomi Islam seperti yang dijelaskan oleh Abdurahman al-Maliki (2001) dalam bukunya, As-Siyâsah al-Iqtishâdiyah alMutslâ (Politik Ekonomi Ideal) adalah jaminan pemenuhan atas pemuasan semua kebutuhan primer (sandang, pangan, dan papan) setiap orang serta pemenuhan kebutuhan sekunder dan tersiernya sesuai dengan kadar kemampuannya sebagai individu yang hidup dalam masyarakat tertentu yang memiliki gaya hidup yang khas. Politik Ekonomi Islam membedakan Kebutuhan Pokok Individu dengan kebutuhan Pokok Masyarakat termasuk mekanisme pemenuhannya.

\subsubsection{Pemenuhan kebutuhan Pokok Individu}

Islam telah menjamin pemenuhan kebutuhan pokok pangan, sandang, dan papan, dengan mekanmisme yang telah ditetapkan oleh syrait dengan strategi sebagai berikut :

\section{Memerintahkan setiap kepala keluarga untuk bekerja.}

Barang-barang kebutuhan pokok tidak mungkin diperoleh, kecuali manusia berusaha mencarinya. Islam mendorong manusia agar bekerja, mencari rezeki, dan berusaha. Bahkan, Islam telah menjadikan hukum mencari rezeki tersebut adalah fardhu. Banyak ayat dan hadis yang telah memberikan dorongan dalam mencari nafkah, diantaranya :

Didalam ayat Al Qur'an surat Al Jumu'ah ayat 10 Allah SWT berfirman : 


\section{نْ تُفْلِحُونَنَ}

“...Maka bertebaranlah kamu di muka bumi, dan carilah karunia Allah dan ingatlah Allah sebanyak-banyaknya supaya kamu beruntung" (QS al-Jumu'ah :10).

Adapun hadits banyak sekali hadits yang memotivasi seorang muslim untuk bekerja diantaranya :

"Tidaklah seorang di antara kamu, makan suatu makanan lebih baik daripada memakan dari hasil keringatnya sendiri" (HR. Baihaqi).

Barangsiapa pada malam hari merasakan kelelahan dari upaya keterampilan kedua tangannya pada siang hari maka pada malam itu ia diampuni." (HR. Ahmad).

"Sesungguhnya di antara perbuatan dosa ada dosa yang tidak bisa terhapus oleh shaum dan Shalat. Ditanyakan pada beliau : 'Apakah yang dapat menghapuskannya, Ya Rasulullah ?" Jawab Rasul saw: "Bekerja (kesusahan) dalam mencari nafkah penghidupan"(HR. Abu Nu'aim).

2. Negara wajib menciptakan lapangan kerja bagi rakyatnya, agar rakyat bisa bekerjsa dan berusaha.

Rasulullah saw pernah memberi dua dirham kepada seseorang dan bersabda,

$$
\text { "كُلْ بِأَحَدِهِمَا وَاشْتَرِ بِآلآخَرِ فَأْسَا وَاعْمَلْ بِهِ }
$$

“makanlah dengan satu dirham, dan sisanya, belikanlah kapak, lalu gunakanlah ia untuk bekerja

3. Islam Mewajibkan kepada kerabat dan muhrim yang mampu untuk memberi nafkah yang tidak mampu. (lihat Q.S 2 :233)

"Kewajiban ayah memberi makan dan pakaian kepada para ibu dengan cara yang makruf. Seorang tidak dibebani selain menurut kadar kesanggupannya. Janganlah seorang ibu menderita kesengsaraan karena anaknya dan seorang ayah karena anaknya, dan ahli waris pun berkewajiban demikian..." (QS al-Baqarah : 233).

4. Kewajiban negara (Baitul Maal) untuk memenuhi jika tidak mampu bekerja dan tidak ada ahli waris yang mampu menafkahinya.

Negara wajib memenuhi kebuthan pokok rakyatnya bagi yang tidak mampu bekerja dan tidak memeliki ahli waris baik dananya berasal dari harta zakat yang merupakan kewajiban syar'i, dan diambil oleh negara dari orang-orang kaya maupun dari harta milik negara, sebagaimana firman Allah SWT.:

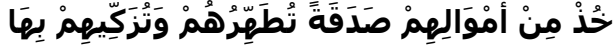

“Ambillah zakat dari sebagian harta mereka, dengan zakat itu kamu membersihkan dan mensucikan mereka...” (QS at-Taubah : 103).

\section{Pemenuhan Kebutuhan Pokok Masyarakat}

Pendidikan, kesehatan, dan keamanan adalah kebutuhan asasi dan harus dikecap oleh manusia dalam hidupnya. Berbeda dengan kebutuhan pokok berupa barang (pangan, sandang, dan papan), saat Islam melalui negara menjamin pemenuhannya melalui mekanisme yang bertahap, maka terhadap kebutuhan jasa pendidikan, kesehatan, dan keamanan negara wajib secara langsung memenuhi kepada setiap individu rakyat.

Adapun dalil yang menunjukkan bahwa keamanan adalah salah satu kebutuhan jasa pokok adalah sabda Rasulullah SAW.:

$$
\text { مَنْ أَصْبَحَ آمِنًا فِين سَرْبه، مُعَافِيَ فِيْ بَدَنِهِ عِنْدَهُ فُوْتُ يَوْمِهِ فَكَاََنَمَا حِيْزَتْ لَهُ الدُّنْيَا بِحَذَافِيْرِهَا }
$$

"Barang siapa yang ketika memasuki pagi hari mendapati keadaan aman kelompoknya, sehat badannya, memilliki bahan makanan untuk hari itu, maka seolah-olah dunia telah menjadi miliknya" (Al-Hadis).

Adapun dalil bahwa yang menjamin terpenuhinya keamanan tersebut adalah negara adalah tindakan Rasulullah SAW. yang bertindak sebagai kepala negara yang memberikan keamanan kepada setiap warga negara (muslim dan nonmuslim/kafir $d z i m m i$ ) sebagaimana sabdanya :

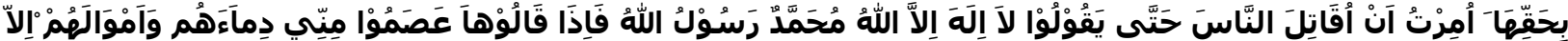

"Sesungguhnya aku diperintahkan untuk memerangi manusia sampai mereka mengucapkan Laa ilaha illallahu Muhammadur Rasulullah. Apabila mereka telah melakukannya (masuk Islam atau tunduk pada aturan Islam), maka terpelihara olehku darah- 
darah mereka, harta-harta mereka, kecuali dengan jalan yang hak. Adapun hisabnya terserah kepada Allah" (HR Bukhari, Muslim, dan pemilik sunan yang empat).

Pendidikan juga Tanggung Jawab Negara, dalam masalah pendidikan Rasulullah saw bersabda :

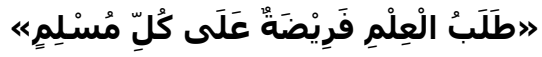

“Mencari ilmu adalah kewajiban atas setiap muslim."[HR. Thabarni].

Begitu juga Rasulullah pernah menetapkan kebijakan terhadap tawanan perang Badar, apabila seorang tawanan telah mengajar 10 orang penduduk Madinah dalam hal baca dan tulis akan dibebaskan sebagai tawanan

Begitu pula yang dilakukan oleh khalifah setelahnya, Ad-Damsyiqy menceritakan suatu kisah dari al-Wadliyah bin Atha', yang mengatakan bahwa di kota Madinah ada tiga orang guru yang mengajar anak-anak. Oleh khalifah 'Umar bin Khaththab ra guruguru tersebut digaji 15 dinar tiap bulannya

Sementara dalam masalah kesehatan Rasulullah saw pernah membangun tempat pengobatan untuk orang-orang sakit dan membiayainya dengan harta dari Baitul Maal

Pada masa Rasulullah saw, beliau saw pernah mendapat hadiah dari Muqauqis seorang dokter. Oleh Rasulullah saw dokter tersebut dijadikan sebagai dokter umum untuk seluruh rakyat. Kedua hal tersebut menunjukkan bahwa kebutuhan pemeliharaan kesehatan rakyat menjadi tanggungjawab negara.

\subsection{Mekanisme Pembiayaan Negara}

Mekanisme Pembiayaan negara dalam sistem ekonomi islam merupakan aplikasi politik ekonomi dalam pengelolaan keuangan negara untuk merealisasikan tujuan politik ekonomi Islam. Karena itu anggaran negara sebenarnya merupakan kebijakan negara, baik menyangkut sumber-sumber pendapatan negara maupun alokasi penggunaan dana dalam rangka mewujudkan terpenuhinya kebutuhan pokok individu orang-perorang dan kepentingan individu yang bersifat sekunder maupun tersiernya.

\subsubsection{Sumber Pendapatan Negara}

Abdul Qadim Zallum (1983) dalam bukunya, Al-Amwâl fî Dawlah al-Khilâfah (Sistem Keuangan Negara Khilafah), secara panjang lebar telah menjelaskan sumber-sumber pemasukan negara. Dalam buku tersebut dijelaskan sumber-sumber pemasukan Negara Khilafah yang dikumpulkan oleh lembaga yang disebut Baitul Mal, yaitu lembaga keuangan Negara Islam, yang mempunyai tugas khusus menangani segala harta umat, baik berupa pendapatan maupun pengeluaran negara

Secara garis besar, pendapatan negara yang masuk ke dalam Baitul Mal di kelompokkan menjadi 4 sumber:

\section{Pengelolaan Negara atas Kepemilikan Umum.}

Benda-benda yang termasuk dalam kepemilikan umum dapat dikelompokkan menjadi tiga kelompok:

a. Fasilitas umum.

Fasilitas umum adalah apa saja yang dianggap sebagai kepentingan manusia secara umum; jika tidak ada dalam suatu negeri atau suatu komunitas akan menyebabkan kesulitan dan dapat menimbulkan persengketaan. Contoh: air, padang rumput, api (energi), dan lain-lain.

b. Barang tambang dalam jumlah sangat besar.

Barang tambang dalam jumlah sangat besar termasuk milik umum dan haram dimiliki secara pribadi. Contoh: minyak bumi, emas, perak, besi, tembaga, dll.

c. Benda-benda yang sifat pembentukannya menghalangi untuk dimiliki hanya oleh individu.

Ini meliputi jalan, sungai, laut, danau, tanah-tanah umum, teluk, selat, dan sebagainya.

Potensi Indonesia untuk pendapatan negara yang berasal dari kepemilikan umum bisa dilihat dari sebagian sumber-sumber di bawah ini:

a. Potensi tambang.

Indonesia adalah salah satu negara yang memiliki potensi hasil tambang yang cukup besar. Sebagian potensi hasil tambang Indonesia dapat dilihat dalam Tabel 2 di bawah ini:

Tabel 2. Potensi Hasil Tambang Indonesia

\begin{tabular}{lll}
\hline Jenis Tambang & Potensi & Rata-rata Produksi Per tahun \\
\hline Minyak & 9.746 .40 juta barel & 1.252 .000 barel \\
Gas & 176.60 triliun kubik & 3.04 triliun kubik \\
Batu Bara & 145.8 miliar ton & 100.625 .000 \\
Emas & 1.300 ton & 126,6 Ton \\
Timah & - & 34.247 metrik ton \\
\hline
\end{tabular}

Sumber: Hasil pengolahan dari berbagai sumber.

Dari data di atas, untuk nilai emas saja dengan asumsi harga sekarang Rp 140.000 pergram, dihasilkan pendapatan sebesar Rp 17.640 triliun. Dan data untuk minyak belum termasuk cadangan yang baru ditemukan di BLok Cepu yang banyaknya hamper sama dengan yang sudah ditemukan.

Tabel 3. Potensi Laut Indonesia.

\begin{tabular}{ll}
\hline Jenis & Hasil Per tahun \\
\hline Ikan Laut (Potensi Lestari) & 6.400 .000 ton \\
Perairan laut dangkal (Budidaya) & 47.000 .000 ton \\
Lahan Pesisir & 5.000 .000 ton \\
\hline
\end{tabular}


Dari potensi laut tersebut, diperkirakan potensi pendapat dari sektor kelautan adalah sebesar US\$ 82 miliar dengan asumsi 1 \$ sebesar Rp 10.000. Artinya, dari potensi laut dapat dihasilkan pendapatan sebesar Rp 820 triliun.

\section{b. Potensi Hutan dan Perkebunan.}

Potensi hutan Indonesia juga cukup tinggi. Hasil hutan dalam bentuk kayu saat ini diperkirakan sebesar US\$2.5 miliar. Hasil hasil ekspor tumbuhan dan satwa liar tahun 1999 sebesar US\$1.5 miliar. Hasil hutan lainnya adalah rotan; Indonesia saat ini memasok sekitar 80 sampai 90\% kebutuhan dunia.

\section{Pengelolaan Fai ,Khoroj, Ghonimah dan Jizyah serta Harta Milik Negara dan BUMN lainya)}

Jenis pendapatan kedua adalah pemanfaatan harta milik negara dan BUMN. Harta milik negara adalah harta yang bukan milik individu tetapi juga bukan milik umum. Harta milik negara bisa berasal dari Fai ,Khoroj, Ghonimah dan Jizyah Contoh: gedunggedung pemerintah, kendaraan-kendaraan pemerintah, serta aktiva tetap lainnya. Adapun BUMN bisa merupakan harta milik umum kalau produk/bahan bakunya merupakan milik umum seperti hasil tambang, hasil hutan, emas, dan lain-lain; bisa juga badan usaha yang produknya bukan merupakan milik umum seperti Telkom dan Indosat.

\section{Harta Zakat}

Kelompok yang ketiga ini adalah mekanisme distribusi harta atau kekayaan yang sifatnya non-ekonomi. zakat merupakan bagian dari ibadah oleh karena itu pengambilan dan pendistribusiannya bersifat tauqifi. Zakat dapat dikelompokkan sebagai berikut :

a. Zakat Nuqud (emas dan perak/Uang) dan Perdagangan.

b. Zakat Pertanian dan buah-buahan

c. Zakat ternak.

Sementara pendistribusian hanya diberikan kepada delapan asnaf yang disebutkan di dalam al Qur'an.

\section{Sumber Pemasukan temporal}

Yang masuk dalam kelompok ini pemasukan-pemasukan negara yang bersifat temporal dan non budgeter diantaranya adalah :

a. Infak, Wakaf, Sedekah, dan Hadiah.

b. Harta Penguasa yang ghulul (haram)

c. Harta Orang-orang murtad.

d. Sisa Harta Warisan atau yang tidak memiliki ahli waris .

e. Dharibah.

f. dan lain-lain

Berdasarkan potensi dan sistem APBN Syariah, maka Indonesia tidak akan mengalami defisit APBN dan tidak akan menjadikan Pajak sebagai sumber utama pendapatan negara. Menurut Fahmi Amhar, kalau APBN indonesia menggunakan prinsip syariah akan didapatkan dana tiap tahunnya sebesar Rp. 1. $764 \mathrm{~T}$ hanya dari satu sumber saja yaitu kepemilikan umum yang dikelola oleh negara sebagaimana dijelaskan pada Tabel 3.

Tabel 3. Penerimaan APBN sektor kepemilikan umum

\begin{tabular}{lll}
\hline \multicolumn{1}{c}{ Kepemilikan umum } & \multicolumn{1}{c}{$\begin{array}{c}\text { Penerimaan } \\
\text { (juta dinar) }\end{array}$} & $\begin{array}{c}\text { Penerimaan } \\
\text { (triliun rupiah) }\end{array}$ \\
\hline 1. Minyak & 121,5 & 182,25 \\
2. Gas & 178,9 & 268,35 \\
3. Batubara & 127,5 & 191,25 \\
4. Emas \& Mineral & 33,5 & 50,25 \\
5. BUMN Kelautan & 48,9 & 73,35 \\
6. Hasil Hutan & 666 & 999 \\
JUMLAH & $1.176,3$ & $1.764,45$ \\
\hline
\end{tabular}

Sumber : Amhar (2009)

\subsubsection{Kebijakan Fiskal dalam Sistem Ekonomi Islam}

Sumber-sumber pendapatan Baitul Mal dalam Khilafah Islam yang telah ditetapkan syariat sebenarnya cukup untuk membiayai pengaturan dan pemeliharaan urusan dan kemaslahatan rakyat. Karena itu, sebetulnya tidak perlu lagi ada kewajiban pajak, baik secara langsung maupun tidak langsung.

Syariat Islam telah menetapkan pembiayaan atas berbagai keperluan dan bidang, yang dibebankan kepada Baitul Mal, tentu ketika terdapat harta di Baitul Mal. Namun, ketika di Baitul Mal tidak terdapat harta atau kurang, sementara sumbangan sukarela dari kaum Muslim atas inisiatif mereka juga belum mencukupi, maka syariat menetapkan pembiayaannya menjadi kewajiban seluruh kaum Muslim. Hal itu karena Allah telah mewajibkan yang demikian. Sebab, tidak adanya pembiayaan atas berbagai keperluan dan bidang itu akan menyebabkan bahaya bagi kaum Muslim. Inilah dasar kebijakan fiskal atau pajak dalam daulah khulafah. Allah telah mewajibkan kepada negara dan umat untuk menghilangkan bahaya itu dari kaum Muslim. Rasulullah saw. bersabda:$$
\text { 》الَ ضَرَرَ وَلَا ضِرَارَاَ }
$$

Tidak boleh mencelakakan orang lain dan tidak boleh mencelakakan diri sendiri. (HR Ibn Majah dan Ahmad). 
JKPIs, Vol. 1 No. 1, 2018 | 15

Ada beberapa ketentuan tentang kebijakan dharîbah (pajak) menurut syariat Islam, yang sekaligus membedakannya dengan pajak atau kebijakan fiskal dalam sistem ekonomi kapitalis, yaitu:

1. dharîbah bersifat temporer, tidak bersifat kontinu; hanya boleh dipungut ketika di Baitul Mal tidak ada harta atau kurang.

2. dharîbah hanya boleh dipungut untuk pembiayaan yang merupakan kewajiban bagi kaum Muslim dan sebatas jumlah yang diperlukan untuk pembiayaan wajib tersebut, tidak boleh lebih. Pembiayaan itu adalah:

a. Pembiayaan jihad dan yang berkaitan dengannya seperti: pembentukan dan pelatihan pasukan; pengadaan senjata; dan sebagainya.

b. Pembiayaan untuk pengadaan dan pengembangan industri militer dan industri pendukungnya.

c. Pembiayaan untuk memenuhi kebutuhan pokok orang fakir, miskin, dan ibnu sabil. Dalam sebuah hadis qudsi Allah berfirman:

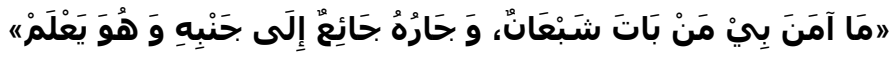

Tidaklah beriman kepada-Ku orang yang tidur dalam keadaan kenyang, sedangkan tetangganya kelaparan di sisinya, dan dia mengetahuinya. (HR al-Bazzar dari Anas).

d. Pembiayaan untuk gaji tentara, hakim, guru, dan semua pegawai negara untuk menjalankan pengaturan dan pemeliharaan berbagai kemaslahatan umat.

e. Pembiayaan atas pengadaan kemaslahatan atau fasilitas umum yang jika tidak diadakan akan menyebabkan bahaya bagi umat semisal: jalan umum, sekolah, rumah sakit, dan sebagainya. Adapun jika untuk menambah yang sudah ada, dan jika tidak dilakukan tidak menyebabkan bahaya, maka tidak boleh ada kewajiban pajak untuk itu.

f. Pembiayaan untuk penanggulangan bencana dan kejadian yang menimpa umat, sementara harta di Baitul Mal tidak ada atau kurang.

3. dharîbah hanya diambil dari kaum Muslim dan tidak dipungut dari non-Muslim. Sebab, dharîbah dipungut untuk membiayai keperluan yang menjadi kewajiban bagi kaum Muslim, yang tidak menjadi kewajiban non-Muslim.

4. dharîbah hanya dipungut dari kaum Muslim yang kaya, tidak dipungut dari selainnya. Orang kaya adalah orang yang memiliki kelebihan harta dari pembiayaan kebutuhan pokok dan kebutuhan lainnya bagi dirinya dan keluarganya menurut kelayakan masyarakat sekitarnya.

5. dharîbah hanya dipungut sesuai dengan jumlah pembiayaan yang diperlukan, tidak boleh lebih.

Dengan demikian, pajak yang dikenakan oleh Negara Islam sangat berbeda dengan sistem pajak dalam sistem kapitalis. Dalam sistem kapitalis pajak merupakan sumber utama pendanaan negara. Sebaliknya, dalam sistem Islam, ia hanya digunakan sebagai penyangga jika kondisi keuangan Negara tidak mencukupi untuk memenuhi kepentingan masyarakat.

\subsubsection{Potret Kesejahteraan Di Masa Kekuasaan Islam.}

Will Durant, dalam The Story of Civilization, vol. XIII, $p$ 151, menggambarkan bagaimana sistem islam yang diterapkan oleh Khalifah mampu memberikan kesejahteraan bagi umat manusia baik muslim maupun non-muslim :

"Para Khalifah telah memberikan keamanan kepada manusia hingga batas yang luar biasa besarnya bagi kehidupan dan kerja keras mereka. Para Khalifah itu juga telah menyediakan berbagai peluang untuk siapapun yang memerlukannya dan memberikan kesejahteraan selama berabad-abad dalam wilayah yang sangat luas, dimana fenomena seperti itu belum pernah tercatat (dalam sejarah) setelah zaman mereka. Kegigihan dan kerja keras mereka menjadikan pendidikan tersebar luas, hingga berbagai ilmu, sastra, filsafat dan seni mengalami kemajuan luar biasa, yang menjadikan Asia Barat sebagai bagian dunia yang paling maju peradabannya selama lima abad".

Begitu juga yang di kemukakan oleh Paul Kennedy dalam bukunya -The Rise and Fall of The Great Powers: Economic Change an Military Conflict from 1500 to 2000). ketika mendiskusikan Kekhilafahan Islam yang terakhir, yakni Kekhilafahan Utsmani, Paul Kennedy menulis, :

"Empirium Utsmani adalah lebih dari sekadar mesin militer; dia telah menjadi penakluk elit yang telah mampu membentuk satu kesatuan iman, budaya dan bahasa pada sebuah area yang lebih luas dibandingkan dengan yang pernah dimiliki oleh Empirum Romawi dan untuk jumlah penduduk yang lebih besar. Dalam beberapa abad sebelum tahun 1500, Dunia Islam telah jauh melampui Eropa dalam bidang budaya dan teknologi. Kota-kotanya demikian luas, rakyatnya terpelajar, perairannya sangat bagus. Beberapa kota di antaranya memiliki universitas-universitas dan perpustakaan yang lengkap dan memiliki masjid-masjid yang indah. Dalam bidang matematika, kastografi, pengobatan dan aspek-aspek lain dari sains dan industri, kaum Muslim selalu berada di depan." (sumber : www.dakwahkampus.com)

Dalam sistem ekonomi Islam, kesejahteraan diukur berdasarkan prinsip terpenuhinya kebutuhan setiap individu masyarakat, bukan atas dasar penawaran dan permintaan, pertumbuhan ekonomi, cadangan devisa, nilai mata uang ataupun indeks hargaharga di pasar non-riil. Inilah sistem ekonomi Islam yang benar-benar akan menjamin kesejahteraan masyarakat dan bebas dari guncangan krisis ekonomi.

Sistem ini terbukti telah mampu menciptakan kesejahteraan umat manusia-Muslim dan non-Muslim-tanpa harus selalu berhadapan dengan krisis ekonomi yang secara berkala menimpa, sebagaimana dialami sistem ekonomi Kapitalisme.

Pada masa Khalifah Umar bin al-Khaththab (13-23 H/634-644 M), misalnya, hanya dalam 10 tahun masa pemerintahannya, kesejahteraan merata ke segenap penjuru negeri. Pada masanya, di Yaman, misalnya, Muadz bin Jabal sampai kesulitan menemukan seorang miskin pun yang layak diberi zakat (Abu Ubaid menuturkan, Al-Amwâl, hlm. 596). Pada masanya, Khalifah Umar bin al-Khaththab mampu menggaji guru di Madinah masing-masing 15 dinar (1 dinar=4,25 gr emas).

Lalu pada masa Khalifah Umar bin Abdul Aziz (99-102 H/818-820 M), meskipun masa Kekhilafahannya cukup singkat (hanya 3 tahun), umat Islam terus mengenangnya sebagai khalifah yang berhasil menyejahterakan rakyat. Yahya bin Said, seorang petugas 
zakat masa itu, berkata, "Ketika hendak membagikan zakat, saya tidak menjumpai seorang miskin pun. Umar bin Abdul Aziz telah menjadikan setiap individu rakyat pada waktu itu berkecukupan." (Ibnu Abdil Hakam, Sîrah 'Umar bin Abdul 'Azîz, hlm. 59).

Pada masanya, kemakmuran tidak hanya ada di Afrika, tetapi juga merata di seluruh penjuru wilayah Khilafah Islam, seperti Irak dan Bashrah. Begitu makmurnya rakyat, Gubernur Bashrah saat itu pernah mengirim surat kepada Khalifah Umar bin Abdul Aziz, "Semua rakyat hidup sejahtera sampai saya sendiri khawatir mereka akan menjadi takabur dan sombong." (Abu Ubaid, AlAmwâl, hlm. 256).

Pada masa keemasan bahkan di akhir kekuasan kekhilafahan Ustmani kita temukan surat-surat khalifah yang menunjukkan kehebatan khilafah Utsmaniyah dalam menjamin, melindungi, dan memakmurkan warganya ataupun orang asing pencari suaka tanpa pandang bulu. Tertua ialah surat sertifikat tanah yang diberikan tahun 1519 kepada para pengungsi Yahudi yang lari dari kejamnya Inkuisisi Spanyol pasca jatuhnya pemerintahan Islam di Al-Andalus. Kemudian surat ucapan terima kasih dari Pemerintah Amerika Serikat atas bantuan pangan yang dikirim khalifah ke sana yang sedang dilanda kelaparan (pasca perang dengan Inggris) abad ke-18. Lalu surat jaminan perlindungan kepada Raja Swedia yang diusir tentara Rusia dan menari eksil kepada khalifah pada 7 Agustus 1709. Surat tertanggal 13 Robi'ul Akhir 1282 H (5 September 1865) yang memberi izin dan ongkos kepada 30 keluarga Yunani yang beremigrasi ke Rusia namun kembali ke wilayah khilafah, karena di Rusia justru mereka sengsara. Yang termutakhir ialah peraturan bebas cukai barang bawaan orang-orang Rusia yang mencari eksil ke wilayah khilafah pasca Revolusi Bolshevik tertanggal 25 Desember 1920 M.

\section{KESIMPULAN}

Berdasarkan hasil pembahasan maka dapat disimpulkan bahwa Pertama, Kegagalan Sistem Ekonomi Kapitalis dalam menyejahterakan Umat Manusia disebabkan karena kesalahan yang mendasar dari sistem tersebut yaitu, pandangan tentang konsep kelangkaan (scarcity) barang dan jasa, pandangan tentang konsep nilai (value) suatu barang dan jasa yang dihasilkan serta pandangan tentang konsep harga dan peranannya dalam produksi, konsumsi, dan distribusi. Kedua, Politik Ekonomi Islam melalui mekanisme langsung dan tidak langsung mampu memberikan jaminan kesejahteraan kepada umat manusia. Ketiga, Sumber pembiayaan Negara dalam sistem ekonomi islam berasal dari Pengelolaan Negara atas kepemilikan umum, Pengelolaan : Fai ,Khoroj, Ghonimah dan Jizyah serta Harta Milik Negara dan BUMN lainya, Harta Zakat serta Pemasukan Temporal.

\section{REFERENSI}

Amhar, F. (2009). Mencoba meramu APBN Syariah. http://famhar.multiply.com/journal/item/179

An-Nabhani, T. (1996). An-Nizām al-Iqtisād fi al-Islām (Membangun Sistem Ekonomi Alternatif-Perspektif Islam), Alih bahasa Moh Maghfur Wachid. Surabaya: Risalah Gusti.

Durant, W. (1939). Story Of Civilization Part-2. New York: Simon and Schuster.

Indonesia, H.T. (2011). Hidup Sejahtera dalam Naungan Khilafah, Naskah Konferensi Rajab.

Nasim, A. (2006). Bagaimana Utang Kita?. Republika.

Nasim, A. (2006). Dampak Buruk kapitalisme. Al-Wa'ie, 88.

Nasim, A. (2011). Kegagalan Sistem Ekonomi Kapitalis dan Prospek Penerapan Sistem Ekonomi Islam, TEMILNAS X FOSSEI.

Suharto, E. (2008). Islam dan Negara Kesejahteraan, Perkaderan Darul Arqom Paripurna (DAP) Ikatan Mahasiswa Muhammadiyah. Triono, D.C. (2010) Kegagalan Sistem Ekonomi Kapitalis, Seminar Nasional Ekonomi Islam.

Zallum, A.Q. (1983). Al Amwal fi Daulatil Khilafah. Beirut : Darul Ilmi lil Malayin . 